\title{
O Desdobrar das personagens mascaradas na construção do persona- gem Figureiro no Cavalo Marinho
}

\section{Ewerton Domingos Ribeiro (IC)}

\section{Resumo}

O objetivo dessa pesquisa é investigar a construção das corporeidades do personagem Figureiro no Cavalo Marinho, visando compreendê-las em jogo, bem como aproximar-se da tradição de aprendizado dos brincantes da Zona da Mata Norte de Pernambuco. O olhar, aqui, lançado às formas espetaculares brasileiras busca conferir estofos à projeção de cenas teatrais, acreditando ser este um terreno fértil ao nosso fazer. Deu-se a conjugação de uma metodologia específica, de amplo espectro, a qual opera com encontros performativos em ida a campo, laboratórios de criação cênica e bibliografia previamente selecionada.

Palavras Chave: Teatro, Cavalo Marinho, Máscara.

\section{Introdução}

A parceria nascida do trabalho conjunto do Grupo Candeia de Teatro e Quebra-Galho resultou na formulação de uma pesquisa que visa o estudo de uma linguagem cênica por meio da cultura popular e do treinamento de máscara para $o$ ator.

\section{Resultados e Discussão}

A dramaturgia do encontro: passagens entre pessoas e suas manifestações

Partindo do pressuposto da alteridade, força que nos faz olhar atentamente para as manifestações espetaculares brasileiras, a tônica dessa pesquisa se dá embasada e desenvolvida nas potencialidades significantes, nas formas e desdobramentos do encontro, do estarcompartilhado.

Com efeito, as cenas teatrais inferidas estavam embebidas da fricção de universos distanciados, ainda que sob a abóbada de uma só Nação, postos em atrito. Tradição e contemporaneidade, ou, ainda, o popular e a erudição, frutos das experiências vividas nas jornadas pela Zona da Mata-Norte em Pernambuco.

\section{As múltiplas facetas da Máscara Teatral}

A lida com a mascararia implica num exercício de alteridade posto hierarquicamente aos atores que se propõem ao seu uso. Cabe ao ator elevar seu corpo à frequência da força autoritária que lhe é dada. O rosto daquela vida que é tomada pelas mãos está à espera de um corpo que o incorpore.

O Grupo Candeia de Teatro e QuebraGalho, na confecção e no uso de suas máscaras se confrontou com a necessidade de revisão e questionamento dos métodos de treinamento para incorporação de linguagem. Vislumbra-se no presente a atualização ativa das tradições.

\section{Conclusões}

A espetacularidade popular brasileira se abre como um horizonte de infindável aprendizado ao fazer teatral, e são muitos os pontos de contato que aproximam um e outro. Nos ciclos performativos das manifestações populares observam-se transposições que fazem confundir, num estado liminar, performer-ator-brincante, de tal modo que o acontecimento teatral se dá sob uma ótica análoga às brincadeiras nos terreiros dos canaviais.

A observação das figuras do Cavalo Marinho e, consequentemente, dos figureiros que as materializam, fazem inferir sobre aspectos formais do corpo-sambador. Sugerem-se, portanto, traços pares ao treinamento para o uso não só da máscara teatral como de outras linguagens dessa esfera. Tradição se re-presentifica, tornando difusas as fronteiras entre o ofício artístico e a vida dos brincantes, na carne e na alma.

\section{Agradecimentos}

Artur Mattar, Pedro Paes, Gracia Navarro, Kaian Ciasca, Carolina Banin, Luiza Pinto, Aguinaldo Roberto da Silva e demais Mestres da Zona da Mata-Norte (PE), Tiche Vianna, Alício Amaral, Juliana Pardo, Ana Maria Carvalho

\footnotetext{
FO, Dario. Manual Mínimo do Ator. Franca Rame (organização); Lucas Baldovino, Carlos David Szlak (tradução). São Paulo: Editora Senac São Paulo, 2004.

${ }^{2}$ OLIVEIRA, E. J. S. A roda do mundo gira: um olhar sobre o Cavalo Marinho Estrela de Ouro (Condado-PE). Recife: Sesc, 2006. ${ }^{3}$ SCHECHNER, Richard. Performance e Antropologia de Richard Schechner, Zeca Ligiéro (organização), Augusto Rodrigues da Silva Junior ... et al. (tradução). Rio de Janeiro: Mauad X, 2012.

${ }^{4}$ SCHECHNER, Richard. Pontos de Contato entre o pensamento antropológico e teatral. Ana Letícia de Fiori (tradução) in Cadernos de Campo, São Paulo, n.20, 2011
} 